A. SHAKHOV, V. PITERSKA

\title{
RISK MANAGEMENT MECHANISMS FOR PROJECT IMPLEMENTATION WITHIN THE FRAMEWORK OF INNOVATIVE PROGRAMS
}

The subject matter of the article is the methods, models and mechanisms of risk-based management of innovative programs. The goal of the work is to develop a risk management mechanism for innovation projects implemented as part of the innovative programs implementation taking into account insurance methods. The following tasks were solved in the article: analysis of the innovation management model of enterprises and organizations in Ukraine and abroad, the study of modern risk management methods for innovative projects, the development of a risk insurance mechanism for innovative programs taking into account the project management methodology. The following methods are user: project and program management methods, systems theory and systems analysis, risk management methods. The following results were obtained: the definitions of innovation, innovation activity management, innovation program, innovation project risk were clarified; the main types of risks arising from the implementation of innovation programs were identified; a mechanism of risk-oriented innovation activity management based on the project management methodology taking into account risk insurance methods was proposed. Conclusions: The paper analyzes the features of the implementation of innovative activities. It is established that the peculiarity of the implementation of innovative projects is the significant uncertainty of the results. It is indicated that during the initiation and implementation of an innovation program, it is necessary to determine the probability of its successful implementation based on the use of risk management models and methods in accordance with the ISO 31000 standard. The paper shows the appropriateness of applying the insurance method when implementing risk management mechanisms of the innovation program. Moreover, it was prescribed that the level of risk in the development and commercialization of products of innovative projects is directly dependent on the degree of innovation of the innovation, that is, the higher the novelty of the innovative product, the higher the risk level relative to its relevance. The use of insurance mechanisms in managing the risks of the innovation program allows to transfer part of the risks of program participants to insurance companies in the amount of a certain calculated insurance amount. It has been established that insurance of risks of the innovation program does not change the existing risk parameters, but provides protection against possible adverse financial consequences of the implementation of the risk, which is important in the conditions of implementation of products of innovative projects. To reduce the cost of insurance and related expenses of organizations within the framework of the implementation of the innovation program, this tool should be used in combination with other methods of risk management of organizations.

Keywords: project and program management; risk management; innovation program; insurance.

\section{Introduction}

In the second half of the $1990 \mathrm{~s}$, the governments of almost all Western European countries adopted programs to stimulate and develop innovation aimed at spreading innovation in countries. Efforts have been made in all Western European countries to form structural elements and mechanisms for implementing innovation policy.

The most favorable climate for the development of innovative entrepreneurship was created in the countries of Northern Europe, which allowed them to become leaders in innovative development in the Western European region. The countries of Northern Europe, as well as Great Britain, Germany and France are the most active participants in innovative cooperation through the EU.

In the countries that are leaders in the field of innovation, there is a concentration of the world's largest financial flows, a significant concentration of the most profitable industries of high-tech products with the highest value added in the price of the product. In these countries, the industrial and technological cycle of environmentally friendly and resource-intensive production of innovative products is made outside the state.

In the world literature, innovation is interpreted as the transformation of potential scientific and technological progress into real, embodied in new products and technologies [1].

Stimulating the development of innovation cannot be limited to a one-time stimulation of only one type of research or development through budget funding (direct funding or taxation).

The level of uncertainty of the results of innovative activities is associated with the difficulty of attracting sources of funding, lack of skills, the complexity of their motivation, organizational aspects of the creation and operation of knowledge-intensive enterprises, features of the production cycle, imperfections [2].

However, high risk is accompanied by a significant degree of compensation that is high profits from the implementation of innovation results.

Research costs are certainly a necessary component of successful development, but due to the increased risk, most companies around the world are quite wary of fundamentally new developments, preferring to go the way of slightly improving existing products and technologies. It should be clearly understood that a certain part of innovation projects inevitably turns out to be unrealized. This is evidenced by the fact that of the total number of projects related to the development and marketing of new products, about $40 \%$ of projects related to the production of consumer goods, $20 \%$ of projects related to the production of goods industrial purposes and $18 \%$ of projects related to the provision of services [3]. At the same time, about $50 \%$ of the costs of creating and promoting innovations fall on products that have not found demand, and 30\% of innovations that have gained market recognition, are kept there for a very short time [4].

For example, in the United States, about $60 \%$ of research and development does not reach the market. 
According to US analysts, of the 11,000 innovative products produced by 77 companies, only $56 \%$ remained on the market five years later, only 1 in 13 promising innovative projects is put into practice, $46 \%$ of the cost of creating and promoting innovation is accounted for by goods that have not been sold [5].

\section{Analysis of recent research and publications}

For enterprises involved in innovation, ignoring or insufficient consideration of the risk of innovation can lead to many undesirable economic results, including: the formation of excess stocks of unsold products, reduced profits compared to expectations, reduced investment efficiency, unplanned labor costs, material or financial resources, the emergence of lost profits as a result of delays in the implementation of innovative solutions [6, 7].

Despite the potential danger of consequences and losses caused by the realization of one or another type of risk of innovation, innovation is a catalyst for progress, a source of possible profit [8].

In $[9,10]$ the risk of innovation is defined as the probability of losses that occur when an entrepreneurial firm invests in the production of innovations that will not be in demand in the market, as well as when investing in the development of new management decisions that will not give the expected result.

In [11-13] innovation risk means the measured probability of loss of profit or loss of value of the portfolio of financial assets, income from a venture (innovation) project, a venture company as a whole when investing in the production of new goods and services, in the development of new equipment and technology, which may not find the expected demand in the market, as well as when investing in the development of management innovations that will not bring the expected effect.

In [14] innovation risk is interpreted as a type of risk that occurs in any activity related to innovation processes, production of new products, goods, services, their operations, commerce, implementation of socio-economic and scientific and technical projects.

Innovation risk factors caused by uncertainty are all risks that arise in the course of innovation, which can be divided into two groups. External factors are related to the state of the external environment in which the implementation of innovative activities, and include risks due to the activities of the state, the environment and the environment. Internal factors are related to the internal environment of the scientific organization, ie due to the peculiarities of the implemented research project: the risks of staffing associated with the staff of the organization, and technical risks associated with the property [15].

Thus, the intensification of innovation activities of domestic enterprises can be ensured only by developing an effective mechanism for managing innovation risks, which minimizes possible losses and maximizes profits through the development and implementation of riskoriented management system taking into account certain factors.
The project analysis should take into account risk factors, identify as many types of risks as possible and try to minimize the overall risk of innovation.

The purpose of this article is to develop a risk management mechanism for innovative projects that are implemented in the implementation of innovative programs, taking into account the methods of insurance.

\section{Presentation of the main material}

One of the reasons for the failure to master many innovative developments is insufficient consideration of the risk factor. Failures related to the introduction of innovative products on the market are $32 \%$ caused by underestimation of market requirements, $13 \%$ - erroneous sales policy, $14 \%$ - high price of goods, $10 \%$ - errors in determining the time of entry into the market, $8 \%$ - high competition and $23 \%$ - technical imperfections of new products [16]. However, there are other statistics: in the first place is the risk due to errors in determining consumer demand ( $45 \%$ of failures), then - associated with product defects (29\%), insufficient advertising (25\%), overpricing (19\%), competition (17\%), erroneous determination of time to market (14\%) [17].

First, the concepts should be clarified [18].

Innovation is the result of innovative activities in the form of goods, services or technologies that create new value (added value) and contain signs of scientific and technical novelty and the possibility of practical application to obtain a socio-economic effect. Innovative activity is the process of creating new scientific knowledge and transforming it into new types of competitive goods, services or technologies.

Innovation management is a system of organizational-economic and psychological-social models and methods, forms and methods of creating innovations based on the methodology of project, program and portfolio management.

Innovation program is a set of projects combined with a single goal that is to obtain a socio-economic effect from the implementation of the results of innovation (implementation of an innovative product).

An essential feature of innovation is its significant uncertainty. The probability of successful implementation of the program must be taken into account when initiating and executing it. Risk management models and methods in accordance with ISO 31000 should be used to address this issue.

It is the presence of significant risks that forces businesses to be very careful about participating in innovative programs. Risk is the effect of uncertainty on the goal $[19,20]$.

The level of risk that arises when developing and promoting new products is directly dependent on the degree of novelty of the innovation: the higher the novelty, the higher the uncertainty of how the product will be perceived by the market.

One of the factors of successful existence and further development of an innovation-active enterprise is the ability to manage innovation risks, ie the ability to 
anticipate the least costly financial costs necessary and sufficient to reduce the likelihood of risk situations, and in case of their occurrence - the ability to localize negative events. The risk management system of innovations in the enterprise should be built on a single methodological basis, but should have a different degree of detail, depending on the type of innovation.

The need to study the causal links and ways to reduce the consequences of the risks of innovation is due to the presence of many forms of risk of innovation with different consequences that need to be prevented and eliminated in a timely manner.

The main results of qualitative risk analysis of innovation are:

- identification of specific risks of the research project and the reasons that give rise to them;

- analysis and calculation of the cost equivalent of the hypothetical consequences of the possible realization of these risks;

- proposing measures to minimize damage;

- cost assessment of risks.

Additional, but also very significant results of the qualitative analysis include the determination of the boundary values of the possible change of all factors (variables) of the project that are tested for risk.

The risks of innovative programs are proposed to be divided into the following types [21]:

- the risk of investment unattractiveness of the program;

- risk of lack of necessary resources;

- the risk of non-fulfillment of contractual terms between the participants of the innovation program in terms of quality and quality;

- scientific and technical risks;

- risk of deviation in terms of implementation of stages of the innovation program;

- risk of deviation of parameters of design and development developments;

- the risk of non-compliance of personnel with the requirements of the program;

- negative results of the program (uncompetitive innovative product);

- the risk of non-compliance of the technical level of production with the technical level of the innovative product;

- legal collateral risk;

- risk of patent protection (erroneous choice of the territorial nature of patenting, non-receipt or delay of patenting, restrictions in terms of patent protection);

- the risk of expiration of the license or certificate for the manufacture and use of an innovative product;

- the risk of losing already developed technical solutions;

- the risk of competitors having new technologies for developing an innovative product;

- environmental risk;

- marketing risk.

If we consider the risk management system of innovation, the methods of reducing their level can be divided into the following: distribution method, hedging method, limiting method, reservation method, diversification method, risk transfer, insurance method [22].

In addition to the listed risk management methods, direct impact on managed risk factors is used to reduce the negative consequences or reduce the level of innovation risk, which includes:

- analysis and evaluation of the innovation project;

- verification of candidates for partners in the innovation project;

- planning and forecasting of innovative activity;

- creation of innovative mood of management at all levels of management, neutralization of resistance to changes, stimulation of various initiatives.

The method of risk allocation is to transfer the maximum responsibility for the risk of the participant who can best control it. The distribution of risk between the participants of innovation increases the reliability of achieving results.

The method of diversification provides a reduction in innovation risks through the distribution of research and investment in multidirectional innovation projects that are not directly related to each other. Diversification is the dispersal of innovation risk [22].

The method of limitation involves limiting the maximum amounts of costs, sales, and credits. This method is used by banks to reduce the degree of risk when lending to innovators, and to companies - when selling goods on credit and determining the amount of capital investment in various innovative projects [26].

At the enterprise limitation is realized by establishment of the corresponding internal financial specifications in the course of development of policy of implementation of various aspects of financial activity and does not demand high financial expenses.

The hedging method is an effective way to reduce the risk of adverse changes in price conditions through the conclusion of futures contracts (futures and options). This method is mandatory for the seller and optional for the buyer [22].

The method of redundancy ensures the reliability of the system by forming a reserve, which compensates for the loss due to the failure of one of the elements of the system [22].

The amount of the reserve should be equal to or greater than the amount of possible losses, but the cost of maintaining reserves should not exceed the cost of restoring system failure.

Reservation of funds is advisable in case of losses, which is a consequence of:

- possible refusal of further development of products and termination of the project due to the implementation of a pessimistic scenario of project development;

- excess of total costs allocated according to the project budget;

- exceeding the deadline for completion of the draft directive. Such directive terms of product development can be determined by contracts, orders and other documents. For example, the directive period for the development of small aircraft is determined by three years. 
Transfer (transfer) of risk is a method of reducing innovation risk by concluding appropriate contracts that provide for the transfer of responsibility for the risk to someone else.

This method is used in cases where the magnitude of the possible risk is unacceptable for an innovative enterprise.

Insurance as a method of risk reduction involves the creation of a special fund and its use to overcome by paying insurance compensation for various losses, losses caused by adverse events (insured events) [22].

The peculiarity of insurance is the presence of two parties: a special organization (insurer) that accumulates the relevant funds, and legal entities and individuals (insurers) who make the established payments to the fund Their mutual obligations are regulated by the contract.

Of all the forms of risk management, insurance most fully meets the ideal conditions, as resources to cover the losses of an innovative firm come from insurance companies faster than from any other source.

Thanks to insurance, the state gets the opportunity to relieve itself of the burden of costs on various payments.

The use of insurance as a method of risk sharing of the innovation program allows you to transfer part of the risks of program participants to insurance companies in the amount of a certain sum insured. At the same time, insurance does not change the existing risk parameters, but provides protection against possible adverse financial consequences of the risk, which is very important in the implementation of innovations. To reduce the cost of insurance and the corresponding costs of organizations in the implementation of the innovation program, this tool should be used in combination with other methods of risk management of organizations.

Accordingly, the high risks of innovative projects still remain without sufficient insurance protection, which objectively reduces the opportunities for innovative development.

However, the insurance method of risk minimization has a number of limitations. First of all, it is a high amount of insurance premium established by the insurance organization when concluding an insurance contract, especially when insuring innovation risks.

Another limitation of the use of the insurance method is its unavailability: some risks are not accepted for insurance. Thus, if the probability of a risky event is very high, insurance companies either do not undertake to insure this type of risk, or impose exorbitant payments. Therefore, if the risk cannot be insured, the company should resort to its own sources; use the accumulated reserves and the method of self-insurance.

Insurance is not only a method of reducing innovation risks, but also in itself helps to increase the innovative activity of the economy. To stimulate innovation, you can use such a method as benefits to innovative enterprises for insurance premiums, including mandatory pension, health and social insurance paid to employees of enterprises engaged in innovative activities.

In Ukraine, insurance of scientific activity of higher education institutions does not occur due to the uncertainty of the results of the research project and the high probability of obtaining a non-competitive innovative product. However, according to international experience, innovation insurance is considered appropriate.

When calculating the insurance rate for the innovation program, we will use the insurance payment, which determines the amount to be paid by the participant of the innovation activity to the insurance company to prevent possible losses in the event of a risk situation and ineffective result.

The gross rate for insurance of the results of the innovation program with the inclusion of innovative projects in the portfolio is determined as follows:

$$
U_{g}=\frac{1}{1-f} * \sum_{i=1}^{I} U_{N o i},
$$

where $U_{N o i}$ - net tariff rate for $i$-th project insurance in the portfolio; $f$-share of load in the gross rate (administrative costs of the insurance company).

The net rate is determined by the formula:

$$
U_{N o i}=U_{x t i}^{Y e s}+U_{x t i}^{N o},
$$

where $U_{x t i}^{Y e s}$ - one-time rate for completion of the $i$-th innovation project for the insured payback period $x$ years with insurance period t years; $U_{x t i}^{N o}$ - one-time rate in case of failure of the $i$-th innovation project for the insured payback period of years with an insurance period of $t$ years.

Let's calculate the rate in case of completion of the innovation program:

$$
U_{x t i}^{Y e s}=\frac{N_{t+x} g}{N_{x}\left[(1+g)^{t}-1\right]} S_{i},
$$

where $g$ - rate of return (\% per annum); $S_{i}$ - funds to be received by the participant of the $i$-th innovation project in case of an insured event (insurance amount) during the implementation of the program; $t$ - insurance period; $N_{t+x}$ - the number of projects in the portfolio with a payback period of $t+x$ years; $N_{x}$ - the number of projects in the portfolio with a payback period of $x$ years.

The rate in case of a failed (unprofitable) innovation program is determined by the formula:

$$
U_{x t i}^{N o}=\frac{N_{d x} g}{N_{x}\left[(1+g)^{1}-1\right]}+\frac{N_{d x}^{2}+\ldots+N_{d(x+t-1)}^{t}}{N_{x}\left[(1+g)^{t+x}-1\right]} S_{i},
$$

where $N_{d x}$ - the number of unsuccessful innovation projects in the transition from payback period $x$ to payback period $x+1$.

According to the mathematical transformation, the formula for determining the gross tariff rate takes the form:

$$
U_{g i}=\frac{1}{1-f}\left(\frac{\left(N_{t+x}+N_{d x}\right) g}{N_{x}\left[(1+g)^{t}-1\right]}+\frac{N_{d x}^{2}+\ldots+N_{d(x+t-1)}^{t}}{N_{x}\left[(1+g)^{t+x}-1\right]}\right) S_{i}
$$


In this case, a fair statement for $I$-projects in the probability $P$ : portfolio when incurring costs in the amount $S$ with a

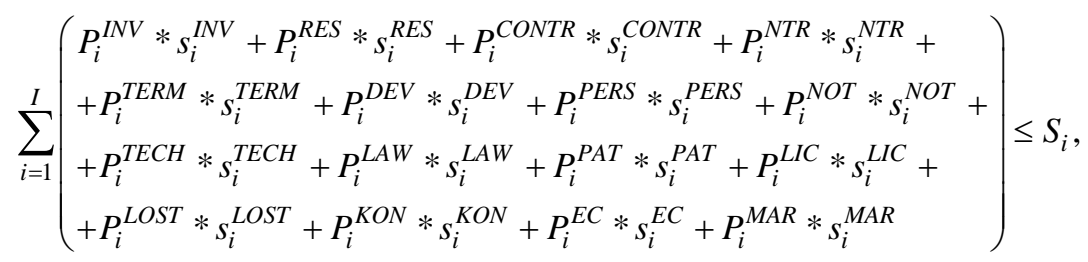

where $P_{i}^{I N V}, s_{i}^{I N V}$ - probability and costs incurred in case of risk of investment unattractiveness of the program, respectively;

$P_{i}^{R E S}, s_{i}^{R E S}$ - probability and costs incurred in the event of a risk of lack of necessary resources, respectively;

$P_{i}^{\text {CONTR }}, s_{i}^{\text {CONTR }}-$ probability and incurred costs in case of risk of non-fulfillment of contractual terms between the participants of the innovation program in terms of quality and quality, respectively;

$P_{i}^{N T R}, s_{i}^{N T R}-$ probability and costs incurred in the event of scientific and technical risk, respectively;

$P_{i}^{T E R M}, s_{i}^{T E R M}-$ probability and incurred costs in case of risk of deviation in terms of implementation of stages of the innovation program, respectively;

$P_{i}^{D E V}, s_{i}^{D E V}$ - probability and incurred costs in case of risk of deviation of design parameters, respectively;

$P_{i}^{P E R S}, s_{i}^{P E R S}-$ probability and costs incurred in case of risk of non-compliance of personnel with the requirements of the program, respectively;

$P_{i}^{N O T}, s_{i}^{N O T}$ - probability and costs incurred in case of risk of negative program results (obtaining a noncompetitive innovative product), respectively;

$P_{i}^{T E C H}, s_{i}^{T E C H}-$ probability and costs incurred in case of risk of non-compliance of the technical level of production with the technical level of the innovative product, respectively;

$P_{i}^{L A W}, s_{i}^{L A W}-$ probability and costs incurred in the event of a risk of legal security, respectively;

$P_{i}^{P A T}, s_{i}^{P A T}$ - probability and costs incurred in case of patent protection risk (erroneous choice of territorial nature of patenting, non-receipt or delay of patenting, limitation in terms of patent protection), respectively;

$P_{i}^{L I C}, s_{i}^{L I C}-$ probability and costs incurred in case of risk of expiration of the license or certificate for the manufacture and use of an innovative product, respectively;

$P_{i}^{L O S T}, s_{i}^{L O S T}-$ probability and incurred costs in case of risk of loss of already developed technical solutions, respectively;

$P_{i}^{K O N}, s_{i}^{K O N}$ - probability and incurred costs in case of risk of competitors developing new technologies for the development of an innovative product, respectively;
$P_{i}^{E C}, s_{i}^{E C}-$ probability and costs incurred in case of environmental risk, respectively;

$P_{i}^{M A R}, s_{i}^{M A R}-$ probability and costs incurred in the event of marketing risk, respectively.

Of course, to achieve more effective results, as a rule, not one, but a set of methods to minimize risks at all stages of innovation is used.

When forming an innovation risk management system, it is necessary to take into account that different projects and their different stages have their own risks and potential profitability. Therefore, one of the main tasks of innovation is the mutual connection of the interests of all actors involved in the implementation of innovative projects.

\section{Conclusions}

An essential feature of the process of implementation of innovative projects is its increased risk, which forces business structures to be very careful to participate in innovation programs. The probability of successful implementation of the innovation program must be taken into account when initiating and implementing it, taking into account the use of risk management models and methods according to ISO 31000 .

The main types of risk situations that arise in the process of implementing innovative programs are identified in the work.

Also, a risk management mechanism for innovative projects has been developed, which allows to provide compensation for possible losses from the occurrence of a risk situation during the implementation of innovative projects on the basis of the insurance method.

For more successful operation of innovation risk insurance mechanisms, the methodology of project and program management should be used, as well as the introduction of comprehensive state support and ensure the normalization of the economic situation in the country. Despite all the problems associated with the introduction of risk insurance mechanisms in innovation, it seems rational that the needs for this type of insurance are objective, given the need to compensate for the costs incurred in case of risk in the implementation of the results of innovation programs. 


\section{References}

1. Malyshkin, N. "University research management" ["Upravleniye nauchno- issledovatel'skoy deyatel'nost'yu v vuze"], available at : https://cyberleninka.ru/article/n/upravlenie-nauchno-issledovatelskoy-deyatelnostyu-v-vuze (last accessed 18.06.2019).

2. Chumachenko, I., Docenko, N. (2011), "Formation of the holistic value of innovative projects and programs" ["Formirovaniye kholisticheskoy tsennosti innovatsionnykh proyektov i programm"], Eastern-European Journal of Enterprise Technologies, Vol. 1 (5), P. 14-16.

3. Bushuyev, S., Bushuev, D., Bushuyeva N., Kozyr B. (2018), "Information technologies for project management competences development on the basis of global trends", Information technology and learning tools, Vol. 68, No. 6, P. 218-234. DOI: https://doi.org/10.33407/itlt.v68i6.2684

4. Armstrong, L. (2002), "A New Game in Town: Competitive Higher Education", Digital Academe: the New Media and Institutions of Higher Education and Learning, New York, Routledge Publ., P. 38-49.

5. Rădulescu, M., Rădulescu, C. Z. (2001), "Project portfolio selection models and decision support", Studies in Informatics and Control, Vol. 10, No. 4, P. 275-286.

6. Kononenkоб I. (2010), "Model and method for optimizing enterprise project portfolios for the planning period" ["Model' i metod optimizatsii portfeley proyektov predpriyatiya dlya planovogo perioda "], Eastern-European Journal of Enterprise Technologies, No. 1/2 (43), P. 9-11.

7. Bushuyev, S., Verenych, O. (2018), "Organizational maturity and project: Program and portfolio success" (Book Chapter), Developing Organizational Maturity for Effective Project Management, P. 2-24.

8. Pavlov, A, Chernov, S., Koshkin, K. (2006), Mathematical bases of project management of high-tech industries [Matematicheskiye osnovy upravleniya proyektami naukoyemkikh proizvodstv], Nikolaev, NUK, $200 \mathrm{p}$.

9. Chernov, S. (2005), "Synergistic effect of project management in high-tech production", Project Management and Production Development, East-Ukrainian National. University, Vol. 3, P. 57-62.

10. Piterska, V., Shakhov, A., Lohinov, O. and Lohinova, L. (2019), "The Method of Transfer of Research Project Results of Institution of Higher Education," 2019 IEEE 14th International Conference on Computer Sciences and Information Technologies (CSIT), Lviv, Ukraine, 2019, P. 77-80. DOI: 10.1109/STC-CSIT.2019.8929887

11. Kosenko, V., Persiyanova, E., Belotskyy, O., Malyeyeva, O. (2017) "Methods of managing traffic distribution in information and communication networks of critical infrastructure systems", Innovative Technologies and Scientific Solutions for Industries, No. 2 (2), P. 48-55. DOI: https://doi.org/10.30837/2522-9818.2017.2.048

12. Bushuyeva, N. (2007), Models and methods of proactive management of organizational development programs [Modeli i metody proaktivnogo upravleniya programmami organizatsionnogo razvitiya], Kiev, Naukovii svit, 270 p.

13. Bushuyev, S., Murzabekova, A., Murzabekova, S., Khusainova, M. (2017), "Develop breakthrough competence of project managers based on entrepreneurship energy", Proceedings of the 12th International Scientific and Technical Conference on Computer Sciences and Information Technologies, CSIT 2017, P. 11-16. DOI: 10.1109/STC-CSIT.2017.8099420

14. Piterska, V. M., Kramskiy, S. O. (2017), "Methodological basis of innovative project-oriented organizations' management", Management of development of complex systems, Kyiv, Ukraine, KNUCA, No. 30, P. 11-20.

15. Dulfer, E. (2002), Projekte und Projektmanagement im internationalen Kontext, Eine Einfuhrung, in: Projektmanagement international, Stuttgart, P. 2-30.

16. Kosenko, V., Gopejenko, V., Persiyanova, E. (2019), "Models and applied information technology for supply logistics in the context of demand swings", Innovative Technologies and Scientific Solutions for Industries, No. 1(7), P. 59-68. DOI: https://doi.org/10.30837/2522-9818.2019.7.059

17. Kononenko I., (2012), "Optimization of the project content according to the criteria of profit, time, cost, quality, risks" ["Optimizatsiya soderzhaniya proyekta po kriteriyam pribyl', vremya, stoimost', kachestvo, riski"], Eastern-European Journal of Enterprise Technologies, No. 1/10 (55), P. 13-15.

18. Piterskaya, V. (2016), "Application of a project-oriented approach in the management of innovation activities" ["Zastosuvannya proektno-oriyentovanoho pidkhodu v upravlinni innovatsiynoyu diyal'nistyu"], Bulletin of National Technical University "KhPI" : coll. of sci. papers. Ser. : Strategic management, portfolio, program and project management, Vol. 1 (1173), P. 35-42 DOI: https://doi.org/10.20998/2413-3000.2016.1173.7

19. Chumachenko, I., Docenko, N., Kosenko, N., Sabadosh, L. (2011) "Formation of an adaptive project team" ["Formirovaniye adaptivnoy komandy proyekta"], Project management and production development, Vol. (38), P. 67-71.

20. Tanaka, K. (2014), "The integration of engineering and program management with the marine economy", Shipbuilding and Marine Infrastructure, Vol. 1 (1), P. 5-9. DOI: https://dx.doi.org/10.15589/smi20140108

21. Piterska, V., Lohinov, O. and Lohinova, L., (2019), "Mechanism for forming an effective portfolio of research projects of institution of higher education", Innovative Technologies and Scientific Solutions for Industries, No. 3 (9), P. 99-108. DOI: https://doi.org/10.30837/2522-9818.2019.9.099

22. Vanyushkin, A., (2008), "Basis for the formation of a portfolio of high-risk projects" ["Osnovaniya dlya formirovaniya portfelya vysokoriskovykh proyektov"], Project Management and Production Development, No. 1 (25), P. 54-61.

Received 15.05.2020

\section{Відомості про авторів / Сведения об авторах / About the Authors}

Шахов Анатолій Валентинович - доктор технічних наук, професор, Одеський національний морський університет, проректор з навчально-організаційної роботи, Одеса, Україна; email: radaonmu@gmail.com; ORCID: http://orcid.org/00000003-0142-7594.

Шахов Анатолий Валентинович - доктор технических наук, профессор, Одесский национальный морской университет, проректор по учебно-организационной работе, Одесса, Украина. 
Shakhov Anatoliy - Doctor of Sciences (Engineering), Professor, Odessa National Maritime University, Vice-Rector for Educational and Organizational Work, Odessa, Ukraine.

Пітерська Варвара Михайлівна - доктор технічних наук, доцент, Одеський національний морський університет, професор кафедри експлуатації портів і технології вантажних робіт, Одеса, Україна; email: varuwa@ukr.net; ORCID: http://orcid.org/0000-0001-5849-9033.

Питерская Варвара Михайловна - доктор технических наук, доцент, Одесский национальный морской университет, профессор кафедры эксплуатации портов и технологии грузовых работ, Одесса, Украина.

Piterska Varvara - Doctor of Sciences (Engineering), Associate Professor, Odessa National Maritime University, Professor of the Department of Port Operations and Cargo Works Technology, Odessa, Ukraine.

\title{
МЕХАНІЗМИ УПРАВЛІННЯ РИЗИКАМИ ПРИ РЕАЛІЗАЦІЇ ПРОЕКТІВ В РАМКАХ ІННОВАЦІЙНИХ ПРОГРАМ
}

\begin{abstract}
Предметом дослідження в статті $є$ методи, моделі і механізми ризико-орієнтованого управління інноваційними програмами. Мета роботи - розробка механізму управління ризиками інноваційних проектів, які реалізуються в рамках виконання інноваційних програм 3 урахуванням методів страхування. В статті вирішуються наступні завдання: аналіз моделі управління інноваційною діяльністю підприємств і організацій в Україні та за кордоном, дослідження сучасних методів управління ризиками інноваційних проектів, розробка механізму страхування ризиків інноваційних програм 3 урахуванням методології проектного управління. Використовуються такі методи: методи управління проектами і програмами, теорія систем і системного аналізу, методи управління ризиками. Отримано наступні результати: уточнені поняття інновації, управління інноваційною діяльністю, інноваційної програми, ризик інноваційного проекту, визначені основні види ризиків, які виникають при реалізації інноваційних програм, запропоновано механізм ризико-орієнтованого управління інноваційною діяльністю, який заснований на методології проектного менеджменту з урахуванням методів страхування ризиків. Висновки: В роботі проведено аналіз особливостей здійснення інноваційної діяльності. Встановлено, що особливістю реалізації інноваційних проектів $є$ значна невизначеність отриманих результатів. Вказано, що при ініціації і виконанні інноваційної програми потрібно визначати ймовірність іiі успішної реалізації на основі використання моделей і методів управління ризиками відповідно до стандарту ISO 31000. В роботі показано доцільність застосування методу страхування при реалізації механізмів управління ризиками інноваційної програми. При цьому встановлено, що рівень ризику при розробці та комерціалізації продуктів інноваційних проектів знаходиться в прямій залежності від ступеня новизни інновації, тобто чим вище новизна інноваційного продукту, тим вище рівень ризику стосовно його затребуваності. Застосування механізмів страхування при управлінні ризиками інноваційної програми дозволяє передати частину ризиків учасників програми страховим компаніям в розмірі деякої розрахованої страхової суми. Встановлено, що страхування ризиків інноваційної програми не змінює існуючі параметри ризику, але забезпечує захистом від можливих несприятливих фінансових наслідків реалізації ризику, що досить важливо в умовах впровадження продуктів інноваційних проектів. Для зниження вартості страхування і відповідних витрат організацій в рамках виконання інноваційної програми даний інструмент доцільно використовувати в комплексі з іншими методами управління ризиком організацій.
\end{abstract}

Ключові слова: управління проектами та програмами; управління ризиками; інноваційна програма; страхування.

\section{МЕХАНИЗМЫ УПРАВЛЕНИЯ РИСКАМИ ПРИ РЕАЛИЗАЦИИ ПРОЕКТОВ В РАМКАХ ИННОВАЦИОННЫХ ПРОГРАММ}

Предметом исследования в статье являются методы, модели и механизмы риск-ориентированного управления инновационными программами. Цель работы - разработка механизма управления рисками инновационных проектов, реализуемых в рамках выполнения инновационных программ с учетом методов страхования. В статье решаются следующие задачи: анализ модели управления инновационной деятельностью предприятий и организаций в Украине и за рубежом, исследование современных методов управления рисками инновационных проектов, разработка механизма страхования рисков инновационных программ с учетом методологии проектного управления. Используются следующие методы: методы управления проектами и программами, теория систем и системного анализа, методы управления рисками. Получены следующие результаты: уточнены понятия инновации, управления инновационной деятельностью, инновационной программы, риска инновационного проекта, определены основные виды рисков, возникающих при реализации инновационных программ, предложен механизм риск-ориентированного управления инновационной деятельностью, который основан на методологии проектного менеджмента с учетом методов страхования рисков. Выводы: В работе проведен анализ особенностей осуществления инновационной деятельности. Установлено, что особенностью реализации инновационных проектов является значительная неопределенность полученных результатов. Указано, что при инициации и выполнении инновационной программы нужно определять вероятность ее успешной реализации на основе использования моделей и методов управления рисками в соответствии со стандартом ISO 31000. В работе показана целесообразность применения метода страхования при реализации механизмов управления рисками инновационной программы. При этом установлено, что уровень риска при разработке и коммерциализации продуктов инновационных проектов находится в прямой зависимости от степени новизны инновации, то есть чем выше новизна инновационного продукта, тем выше уровень риска относительно его востребованности. Применение механизмов страхования при управлении рисками инновационной программы позволяет передать часть рисков участников программы страховым компаниям в размере некоторой рассчитанной страховой суммы. Установлено, что страхование рисков инновационной программы не изменяет существующие параметры риска, но обеспечивает защитой от возможных неблагоприятных финансовых последствий реализации риска, что немаловажно в условиях внедрения продуктов инновационных проектов. Для снижения стоимости 
Сучасний стан наукових досліджень та технологій в промисловості. 2020. № 2 (12)

ISSN 2522-9818 (print)

страхования и соответствующих расходов организаций в рамках выполнения инновационной программы данный инструмент целесообразно использовать в комплексе с другими методами управления риском организаций.

Ключевые слова: управления проектами и программами; управление рисками; инновационная программа; страхование.

Бібліографічні описи / Bibliographic descriptions

Шахов А. В., Пітерська В. М. Механізми управління ризиками при реалізації проектів в рамках інноваційних програм. Сучасний стан наукових досліджень та технологій в DOI: https://doi.org/10.30837/2522-9818.2020.12.082.

Shakhov, A., Piterska, V. (2020), "Risk management mechanisms for project implementation within the framework of innovative programs", Innovative Technologies and Scientific Solutions for Industries, No. 2(12), P. 82-89. DOI: https://doi.org/10.30837/2522-9818.2020.12.082. 